\title{
Transcriptional Analysis of Pseudomonas stutzeri A1501 Associated with Host Rice
}

\author{
Khandakar Mohiul Alam1, Tao Zhang2, Yonglian Yan², Wei Zhang², Min Lin², Wei Lu² \\ ${ }^{1}$ Bangladesh Sugarcrop Research Institute, Ishurdi, Bangladesh \\ ${ }^{2}$ Biotechnology Research Institute, Chinese Academy of Agricultural Sciences, Beijing, China \\ Email: mohiulalam74@yahoo.com
}

Received 5 February 2016; accepted 27 March 2016; published 30 March 2016

Copyright (C) 2016 by authors and Scientific Research Publishing Inc.

This work is licensed under the Creative Commons Attribution International License (CC BY). http://creativecommons.org/licenses/by/4.0/

(c) (i) Open Access

\begin{abstract}
Pseudomonas stutzeri A1501, associative and endophytic nitrogen-fixing bacterium showed the capacity of colonization in the rice roots and considered as the good colonizer in the rice plant. The experiment was conducted to study the expression of genes potentiality relevant to the association of nitrogen fixing Pseudomonas stutzeri with host rice and reveal the molecular mechanism by which underlying interaction between bacteria and host rice. The bacteria were shown to be uniformly distributed on the rhizoplane of the root and the density of bacteria was found at the intercellular junction and micro colony developed on the surface of the epidermal cells and on the cellular junctions. Root exudates of rice were the major components of carbon and energy sources for bacteria. RT-PCR analyses of pilK, metE, rpoN and $f d h E$ genes expression of $P$. stutzeri A1501 were performed at positive and negative (control) conditions. After $1 \mathrm{~h}$, it was found that pilK, metE and rpoN transcription were increased 5.7, 6.4 and 3.4-fold, respectively, whereas in the $f d h E$ gene has no expression. Consequently, after $4 \mathrm{~h}$ pilk, fdhE, metE and rpoN were decreased -1.9, $-4.4,-0.2$ and -0.8 -fold, respectively. The gene pilK, expression was up-regulation after $1 \mathrm{~h}$ and down-regulation after $4 \mathrm{~h}$ that has twitching motility to convey the bacterial cell to point of attachment in to host plant. The gene expressions of the bacteria, pilK, metE, rpoN and $f d h E$ were upand down-regulated during the influence of root exudates which regulated the colonization of bacteria during plant-microbe interaction.
\end{abstract}

\section{Keywords}

Rice, Pseudomonas stutzeri A1501, Transcriptional Analysis, Root Exudates, Colonization

\section{Introduction}

The establishment of beneficial interactions between microbes and their host plants, molecular signaling plays a

How to cite this paper: Alam, K.M., Zhang, T., Yan, Y.L., Zhang, W., Lin, M. and Lu, W. (2016) Transcriptional Analysis of Pseudomonas stutzeri A1501 Associated with Host Rice. Advances in Microbiology, 6, 210-221.

http://dx.doi.org/10.4236/aim.2016.63021 
fundamental role between the partners of bacteria and host. Root exudates of host plant represent an important source of nutrients for microbes and act as signals influenced the ability of microbial strains to colonize the roots and to survive in the rhizosphere [1]. The rhizosphere is a natural microbial environment in which the activity of the microorganisms is maintained at a high level owing to a continuous release of organic substances by the plant roots. Simulation of microorganisms present in the rhizosphere seems to be due to the presence of organic compounds released by the roots and representing up to $20 \%$ plant dry weight [2]. This material includes flanked cells of root cap, mucellage and soluble and non soluble exudates, which may contain free amino acids, proteins, carbohydrstes, alcohols, vitamins, or hormones [3]. In cereals, it has been estimated that $4 \%-29 \%$ of the photosynthetes can be transferred to the rhizosphere which is readily available for consumption for microbes [4]. Chemotactic response of bacteria towards amino acids, sugars and organic acids is a fundamental for bacterial behaviour both in vitro and in situ and represents, probably the first step in root colonization. The capacity of colonization in the rhizosphere of a host plant could be favoured and even increased several components of root exudates, which could induce some temporary modifications in the structure of bacterial lipopolysaccharide [5]. Microbial communities on plant selection are depending on the activation of specific patterns of gene expression in the microbe in response to molecular signals secreted from the plant. The plant attracts nitrogenfixing bacteria to invade the cells in the root and provides them with carbohydrates as a food source while the bacteria reduce nitrous compounds in the soil that are then used by the plant [6]. The interactions of rhizosphere microbes with plants depend on the establishment of intimate associations between the two partners. Theses intimate cooperation between plant and bacteria display a high level of host specificity. There is also a growing body of evidence suggesting that many other associations between plants and microbes show similar degrees of specificity; different plant species, and even different cultivars of the same plant species, establish distinct microbial populations in their rhizosphere when grown in the same soil. The formation of these communities depends, at least in part, on the activation of specific programs of gene expression in the microbe in response to chemical signals secreted from the plant. These signaling processes have profound implications for the design of new strategies to promote those interactions of benefit to the host plant. So far, our knowledge of bacterial endophytes has come from the study of model PGPR, via genomic and functional analysis of candidate genes. As reviewed by Reinhold-Hurek and Hurek [7], several genomes of endophytes are now available, including Azoarcus sp. BH72 [8], Klesiella pneumoniae 342 [9], Pseudomonas stutzeriA1501 [10], Gluconacetobacter diazotrophicus Pal5 [11], Azospirillum sp. B510 [12] and Herbaspirillum seropedicae SmR1 [13]. The exploration of these genomes revealed a number of characteristics that are important for rhizosphere competence. Geneencoding products with relevant functions linked to plant-microbe interactions were identified, such as nitrogen fixation, production of hormones and degradation of ethylene intermediate, iron transport, flagella, pili and quorum sensing that modulate functions related to rhizosphere competence and adaptation. The global approaches based on bacteria in to the plant havetargeted plant transcriptomics [14] [15], proteomics [16] and metabolomic approaches [17]. First results of "omics" approaches were reported with the model plant $A$. thaliana, followed by studies in rice (Oryza sativa), the model plant for monocot species, and more recently in maize. However, very little is known about the effects of root exudates on patterns of bacterial gene expressions involving the establishment of plant-microbe interactions. The objectives of this study are the expression of genes potentiality relevant to the association of nitrogen fixing Pseudomonas stutzeri with host rice and reveal the molecular mechanism by which underlying interaction between bacteria and host rice.

\section{Materials and Methods}

\subsection{Bacterial Strains and Media}

The wild-type bacterial strain of P. stutzeri A1501 used in this study. The media were used LB broth and minimal lactate medium broth (A15) for bacterial growth and; Hoagland's solution and semisolid nutrient solution for rice culture.

\subsection{Sterilization and Germination of Rice Seeds, and Cultivation of Rice Seedlings}

Rice seeds (approximately $15 \mathrm{~g}$ ) were washed with sterile water twice. Seeds soaked by sterile water about 10 min, then used $75 \%$ ethanol to shake the seeds about $2 \mathrm{~min}$. 50\% $\mathrm{NaClO}$ was used to shake the seeds about 10 min and then used 100\% NaClO to shake them about $20 \mathrm{~min}$. 75\% ethanol used to shake the seeds about 5 min. 
Then the seeds were washed by sterile water about 5 - 6 times in the laminar flow cabinet. The seeds were put on the petri dish with 8 layers gauge and ensure that the seeds were not too dense. The petri dish was put on $30^{\circ} \mathrm{C}$ in incubation chamber to sprout of seeds and watered the seeds by sterile water when required (Figure 1).

For root exudates collection, twelve axenic rice plantlets ( 3 - 5 days) cultivated in a sterile hydrophonic system. The system consisted of a beaker with nutrient medium and gauze on which the seedlings were placed. Rice roots were kept in half-strength Hoagland's solution [18] containing 50 mg/l nalidixic acid to avoid development of microorganisms. Rice plants were put on the growth chamber with constant temperature of $26^{\circ} \mathrm{C}$, 12-h day, and 70\% relative humidity [19] for 14 days, adding nutrient solution periodically, under axenic conditions [2] (Figure 2). The components of Hoagland's solution were presented in Table 1.
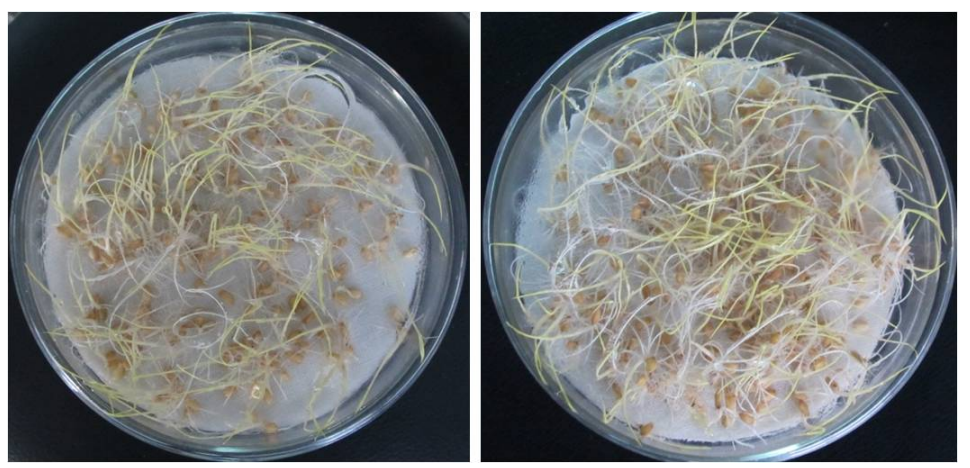

Figure 1. Germinated seedlings of rice.

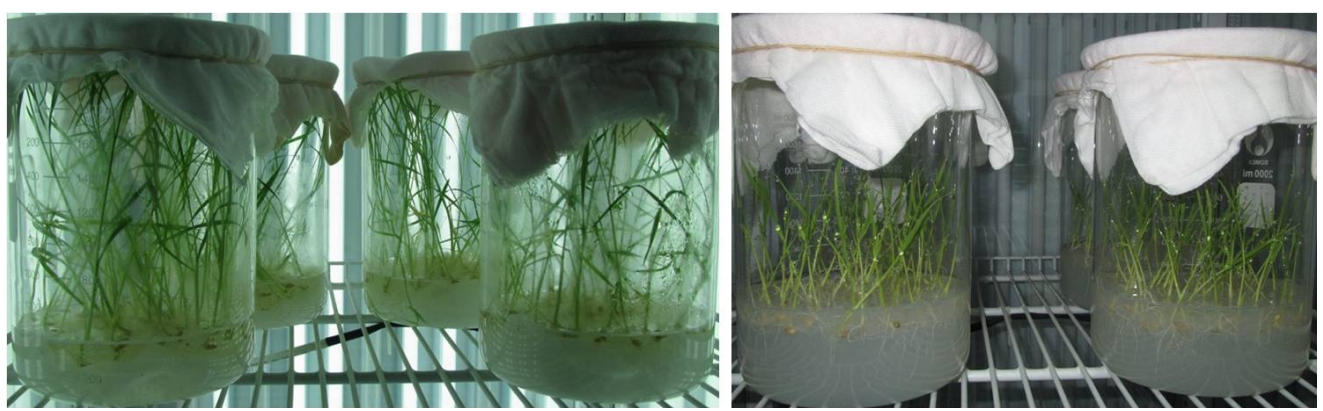

Figure 2. Cultivation of rice in Hoagland solution (left) and semi-solid nutrient solution (right).

Table 1. Component of Hoagland's solution.

\begin{tabular}{ccc}
\hline Components & Stock solution & $\mathrm{mL}$ stock solution/1 L \\
$2 \mathrm{M} \mathrm{KNO}_{3}$ & $202 \mathrm{~g} / \mathrm{L}$ & 2.5 \\
$2 \mathrm{M} \mathrm{Ca}\left(\mathrm{NO}_{3}\right)_{2} \cdot 4 \mathrm{H}_{2} \mathrm{O}$ & $236 \mathrm{~g} / 0.5 \mathrm{~L}$ & 2.5 \\
Iron (Sprint 138 iron chelate) & $15 \mathrm{~g} / \mathrm{L}$ & 1.5 \\
$2 \mathrm{M} \mathrm{MgSO} \cdot 7 \mathrm{H}_{2} \mathrm{O}$ & $493 \mathrm{~g} / \mathrm{L}$ & 1 \\
$1 \mathrm{M} \mathrm{NH}_{4} \mathrm{NO}_{3}$ & $80 \mathrm{~g} / \mathrm{L}$ & 1 \\
$\mathrm{Minors}$ & & 1 \\
$\mathrm{H}_{3} \mathrm{BO}_{3}$ & $2.86 \mathrm{~g} / \mathrm{L}$ & 1 \\
$\mathrm{MnCl}_{2} \cdot 4 \mathrm{H}_{2} \mathrm{O}$ & $1.81 \mathrm{~g} / \mathrm{L}$ & 1 \\
$\mathrm{ZnSO}_{4} \cdot 7 \mathrm{H}_{2} \mathrm{O}$ & $0.22 \mathrm{~g} / \mathrm{L}$ & 1 \\
$\mathrm{CuSO}_{4}$ & $0.051 \mathrm{~g} / \mathrm{L}$ & 1 \\
$\mathrm{H}_{3} \mathrm{MoO}_{4} \cdot \mathrm{H}_{2} \mathrm{O}$ or & $0.09 \mathrm{~g} / \mathrm{L}$ & 1 \\
$\mathrm{Na}_{2} \mathrm{MoO}_{4} \cdot 2 \mathrm{H}_{2} \mathrm{O}$ & $0.12 \mathrm{~g} / \mathrm{L}$ & 0.5 \\
\hline
\end{tabular}


And the components of semisolid nutrient solution (Figure 2) were $50 \mathrm{mg} \mathrm{NaH} \mathrm{NO}_{4}, 88 \mathrm{mg} \mathrm{K} \mathrm{SO}_{4}, 110 \mathrm{mg}$ $\mathrm{CaCl}_{2}, 202 \mathrm{mg} \mathrm{MgSO}_{4} \cdot 7 \mathrm{H}_{2} \mathrm{O}, 1 \mathrm{mg} \mathrm{MnSO}{ }_{4} \cdot \mathrm{H}_{2} \mathrm{O}, 1 \mathrm{mg} \mathrm{FeSO}{ }_{4}, 1 \mathrm{mg} \mathrm{Na} \mathrm{MoO}_{4}, 150 \mathrm{mg}\left(\mathrm{NH}_{4}\right)_{2} \mathrm{SO}_{4}$ and agar $0.25 \%$ for 1 litter with $\mathrm{pH} 6.8$.

\subsection{Root Exudates Collection}

Plants were transferred from the culture solution beaker to jars, where their roots were rinsed consecutively with distilled water and trap solution $\left(1 \mathrm{mM} \mathrm{NH}_{4} \mathrm{Cl}\right.$ and $\left.0.1 \mathrm{mM} \mathrm{CaCl}_{2}\right)$. Finally, the root mass was carefully immersed in a $1 \mathrm{~L}$ dark bottle containing trap solution for $24 \mathrm{~h}$ to collect root exudates. The $\mathrm{pH}$ was monitored every $8 \mathrm{~h}$ during the $24 \mathrm{~h}$ collection period and re-adjusted to $5.6 \pm 0.2$ with $\mathrm{HCl}$ or $\mathrm{NaOH}$ if necessary. After 24 $\mathrm{h}$, the root and shoot tissue were saved for dry matter determination. The trap solution was evaporated to dryness using a rotary evaporator at $40^{\circ} \mathrm{C}$, then re-suspended in $100 \%$ methanol and re-evaporated twice. Finally, the concentrated sample was suspended in $1.0 \mathrm{~mL}$ of $100 \%$ methanol and passed through a syringe-driven $0.22 \mathrm{~mm}$ membrane filter paper. The filtrate was completely evaporated in a centrifuge evaporator, re-suspended in 50 or $100 \mathrm{~mL}$ of dimethyl sulfoxide (DMSO). Control for the trap solution was subjected to the same procedure as for the sample. Other alternative method used as rice plants were placed at top of a paper bottle containing $250 \mathrm{~mL}$ of sterile deionised water. Bottle was aerated and placed in a dark room for 12 hours (modified [20]). Root exudates were filter-sterilized on Whatman no.42 filter paper and $0.22 \mu \mathrm{m}$ filter Millipore and stored at $-20^{\circ} \mathrm{C}$ until use.

\subsection{Determination of Low Molecular Weight Organic Acid from Root Exudates by HPLC}

The root exudation was poured into anion exchange (DEAE) column $(1.2 \mathrm{~cm} \times 8 \mathrm{~cm}, 9 \mathrm{ml}$ DEAE32). The column was washed with $25 \mathrm{ml}$ of deionised water and the organic acids were eluted with $15 \mathrm{ml}$ of $1 \mathrm{MHCl}$. The exudate was dried with rotary evaporator $\left(40^{\circ} \mathrm{C}\right)$. The residue was dissolved with 1 to $2 \mathrm{ml}$ of the HPLC (high-performance liquid chromatography) mobile phase solution of $0.5 \% \mathrm{KH}_{2} \mathrm{PO}$. The mixture was filtered through $0.45 \mu \mathrm{m}$ filter to remove suspended material prior to injection into the HPLC. Separation was conducted on a $150 \times 4.6 \mathrm{~mm}$ reverse phase column (Extend Zorbax). Sample solutions $(20 \mu \mathrm{l})$ were injected into the column with a flow rate of $0.6 \mathrm{ml} \cdot \mathrm{min}^{-1}$ at $50^{\circ} \mathrm{C}$ and UV detection at $210 \mathrm{~nm} .0 .5 \% \mathrm{KH}_{2} \mathrm{PO} 4$ solution was used for isocratic elution. Identification of organic acids was performed by comparing retention times and absorption spectra with those of known standards of different organic acids.

\subsection{Selection of Genes Responsible for Bacteria-Rice Interactions}

The genes were selected from the P. stutzeri A1501 genome (Table 2) which has interactions and colonization capacity to the host plant [1] [10] [19]. For the identification of genes fragments, the primers were designed by using Perl Primer software. The selected primers mentioned at Table 3.

Table 2. List of selected genes used in this study.

\begin{tabular}{lll}
\hline Gene & Functions & Organism \\
\hline$f d h E$ & FdhE protein (Energy metabolism) & P. stutzeri A1501 \\
metE & 5-methyltetrahydropteroyltriglutamate-homocysteine &, \\
pilK & S-methyltransferase (Amino acid biosynthesis and metaboloism) &, \\
$r p o N$ & methyltransferase PilK (Twitching motility) &, \\
\hline
\end{tabular}

Table 3. List of primers used in this study.

\begin{tabular}{lll}
\hline Gene name & Primer & Thermo Tm \\
\hline \multirow{2}{*}{$f d h E$} & F: ACCAAGAAGCTCGACTACC & $54.5^{\circ} \mathrm{C}$ \\
& R: GCCAATTCGAGATAGAGCTG & $57.7^{\circ} \mathrm{C}$ \\
metE & F: TTCGATACCAACTACCACTATCTG & $57.4^{\circ} \mathrm{C}$ \\
\multirow{2}{*}{ pilK } & R: GATCTGTACCCACTCGACTC & $54.5^{\circ} \mathrm{C}$ \\
& F: CTGTTGATCTACTTCCGCC & $55.8^{\circ} \mathrm{C}$ \\
rpoN & R: GAACCTGATCATTGGCAACC & $60.3^{\circ} \mathrm{C}$ \\
& F: TGGCTGGAGAAGAAGTATTTGAG & $55.0^{\circ} \mathrm{C}$ \\
\hline
\end{tabular}




\subsection{Establishment of Bacterium into Root Exudates}

Overnight $10 \mathrm{ml}$ bacterial culture of Pseudomonas stutzeri was inoculated in to the $50 \mathrm{ml}$ of A15 medium and then added $40 \mathrm{ml}$ root exudates in the conical flask, mixed it thoroughly and shaking the flask by the shaker with $150 \mathrm{rpm}$. Bacterial samples were collected after 1 hour and 4 hours. At the same time control sample was run and followed the same procedures and then all collected samples of bacteria were stored at $-80^{\circ} \mathrm{C}$.

\subsection{Colonization of Rice Roots by Pseudomonas stutzeri Strain}

Three days aged rice seedlings of similar root length were selected and inoculated by $20 \mathrm{~mL}$ of a bacterial suspension. This bacterial suspension was made by suspending bacteria in sterile water to OD 600 of 0.10 , then diluting 1:20 with sterile water, giving a bacterial cell count of about $4 \times 10^{6}$ cells per mL. Seedlings were then placed into the appropriate plant growth chamber (Figure 3). The seedlings were examined at 14 days after inoculation to determine the success of the association of the bacteria with the root and the level of invasion into root tissues. To obtain cross sections of the root samples, fresh root segments were fixed in $3.6 \%$ formaldehyde solution in phosphate buffer (0.5 M, pH 7.0) for 2 days, and then rinsed three times with phosphate buffer. Fixed root segments were embedded in 5\% agarose and then sectioned using a Lancer Vibratome Series 1000.

\subsection{Scanning Electron Microscopic Study}

Seedlings of 14 days inoculation were randomly selected for scanning electron microscopic examination. Tissue samples from inoculated seedling roots of rice were fixed in $2 \%$ glutaraldehyde (made up in 0.1 Mcacodylate buffer) in the refrigerator $\left(8^{\circ} \mathrm{C}\right)$ for $1.5 \mathrm{hr}$. Samples were washed two times in the same buffer for $10 \mathrm{~min}$, postfixed in $1 \% \mathrm{OsO}_{4}$ for $4 \mathrm{hrs}$, and dehydrated as follows: 30\%, 50\%, 70\%, 85\%, and 95\% ethanol for 15 min; 100\% ethanol, two times for 15 min each. For the scanning electron microscopy, the Critical Point Drying (CPD) method, sputter coating, and an Amray 1600 scanning electron microscope operating at $20 \mathrm{kv}$ were used. Root vascular systems and rhizobacteria colonization patterns were observed by SEM.

\subsection{Isolation of RNA}

The bacterial samples which were stored at $-80^{\circ} \mathrm{C}$ took it out and transferred to a 1.5 micro centrifuge tubes and it were centrifuged for 2 minutes at $14000 \times \mathrm{g}$. The supernatant removed carefully and the pillet left as dry as possible. The pillet was re-suspended in $100 \mu \mathrm{l}$ fleshy prepared TE containing lisozyme and mixed it gently. The re-suspended pillet was incubated at room temperature at 3 - 5 minutes and added 3 - $5 \mu \mathrm{l}$ of RNA lysis buffer. It was added $350 \mu \mathrm{l}$ RNA dilution buffer and mixed it by inversion and added $200 \mu \mathrm{l}$ ethanol (95\%) to the clear lysate; and mixed by pipeting 3 - 4 times, mixture was transferred to the spin column assembly; and centrifuge at 12,000 $-14,000 \times \mathrm{g}$ for one minute. The spin basket was taken from the spin column assembly, discarded spin basket in the collection tube and put back into the collection tube, it was added $600 \mu \mathrm{l}$ of RNA wash solution to the spin column assembly and centrifuged at $12000-14000 \times \mathrm{g}$ for $1 \mathrm{~min}$. The collection tube did the empty as before and placed it in a rack. It was incubated for $20^{\circ} \mathrm{C}-25^{\circ} \mathrm{C}$. After this incubation, $200 \mu \mathrm{l}$ of DNase stop solution was added and centrifuged at $12000-14000 \times \mathrm{g}$ for $1 \mathrm{~min}$. Then $600 \mu \mathrm{l}$ of RNA wash solution with ethanol was added and centrifuged at $12000-14000 \times \mathrm{g}$ for $1 \mathrm{~min}$. The collection tube did the empty and added 250 $\mu \mathrm{l}$ RNA wash solution and centrifuged at high speed for 2 minutes. The spin basket was transferred from the

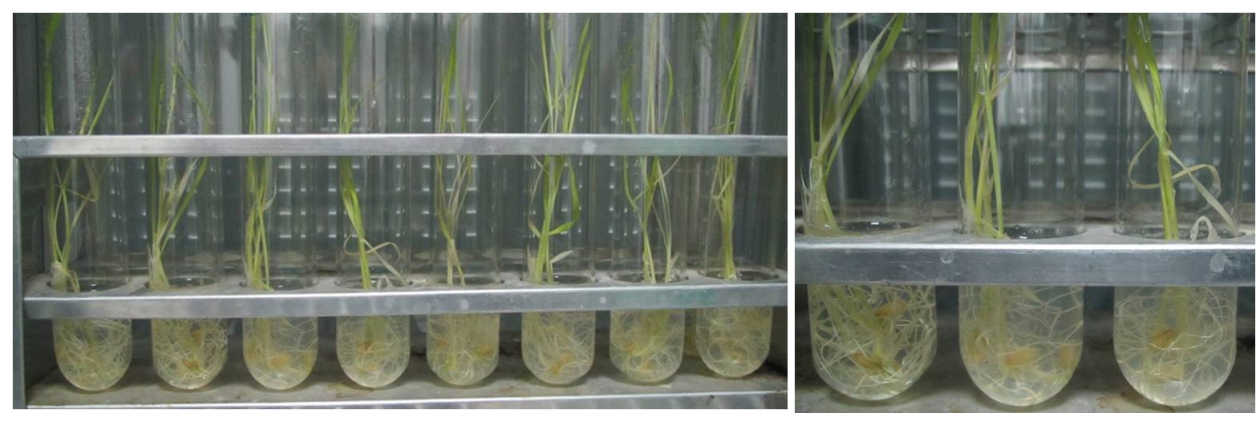

Figure 3. Inoculation of rice roots by Pseudomonas stutzeri. 
collection tube to the elution tube and added $100 \mu$ nuclease free water to the membrane. The spin basket assemblies placed in the centrifuge with lids of the elution tube facing out and centrifuged at $12000-14000 \times \mathrm{g}$ for 1 min. The collected RNA was done gel electrophoresis (Figure 4). The spin basket was removed and discarded. The elusion tube was capped containing the purified RNA and stored at $-80^{\circ} \mathrm{C}$.

\subsection{Conversion to cDNA}

A control reaction without reverse transcriptase to be examined the DNA contamination in the sample. RNA sample and primer d (T) $23 \mathrm{VN}$ mixed in two sterile Rnase-free micro centrifuge tubes. The mixture total volume were $8 \mu \mathrm{l}$ where total RNA was 1 - $6 \mu \mathrm{l}(10 \mathrm{pg}-1 \mu \mathrm{g})$, d (T) $23 \mathrm{VN}(50 \mu \mathrm{M})$ was $2 \mu \mathrm{l}$ and nuclease free $\mathrm{H}_{2} \mathrm{O}$ was variable. The RNA was denatured for 5 minutes at $70^{\circ} \mathrm{C}$, spinned briefly and put promptly on ice. Then the components of $10 \mu \mathrm{l} \mathrm{M-MuLV} \mathrm{Reaction} \mathrm{Mix} \mathrm{and} 2 \mu \mathrm{l} \mathrm{M-MuLV} \mathrm{Enzyme} \mathrm{Mix} \mathrm{were} \mathrm{added} \mathrm{to} \mathrm{one} \mathrm{tube.} \mathrm{For}$ the negative control, $10 \mu \mathrm{l} \mathrm{M-MuLV} \mathrm{Reaction} \mathrm{Mix} \mathrm{and} 2 \mu \mathrm{H}_{2} \mathrm{O}$ were contained another tube. $20 \mu \mathrm{l}$ cDNA synthesis reactions were incubated at $80^{\circ} \mathrm{C}$ for one hour. For the enzyme inactivation, reaction was done at $80^{\circ} \mathrm{C}$ for 5 minutes. The reactions were dilute to $50 \mu \mathrm{l}$ with $30 \mu \mathrm{l} \mathrm{H}_{2} \mathrm{O}$ for PCR. The cDNA product was stored at $-20^{\circ} \mathrm{C}$

\subsection{Reverse Transcription (RT)-PCR}

The PCR reaction was carried out with 70 ng DNA as template $1 \mu \mathrm{M}$ forward and reverse primers. The reaction was cycled 25 times with a $55^{\circ} \mathrm{C}$ annealing temperature and a $2-4$ min extension time at $72^{\circ} \mathrm{C}$, depending on the size of the expected product. The same RNA was used in the PCR reaction as a negative control to test for genomic contamination.

\section{Results}

\subsection{Organic Acids of Root Exudates}

Rice root exudates were provided to HPLC for determination of two organic acids as acetic acid and tartaric acid and it found that the concentrations were 19.84 and $324.12 \mu \mathrm{mol} \cdot \mathrm{g}^{-1}$ dry weight roots, respectively (Table 4). Generally, amino acids, monosaccharides, and organic acids were considered as the major exudates compounds to evaluate the importance of these components for proliferation and root colonization in respect of plant-bacteria interaction.

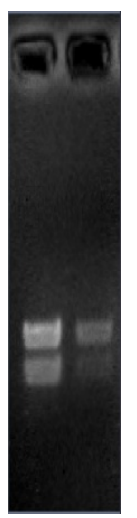

Figure 4. Isolation of total RNA.

Table 4. Low molecular weight organic acid concentrations of rice root exudates ( $\mu \mathrm{mol} \cdot \mathrm{g}^{-1}$ dry weight root).

\begin{tabular}{ccc} 
Name of low molecular acids & $\mu$ mol.g ${ }^{-1} \mathrm{dry}^{\mathrm{w}}$ weight root & 19.84 \\
Acetic acid & 324.12 \\
Tartaric acid & 324 \\
\hline
\end{tabular}




\subsection{Colonization of Rice Roots by P. stutzeri A1501}

Establishment of endophytic colonization of rice plants by $P$. stutzeri A1501 was demonstrated with a gnotobiotic system, using axenic rice plantlets. Interaction between rice roots from 14 dpi (days post inoculation) plantlets and P. stutzeri obtained under gnotobiotic conditions was observed by SEM. Rod-shaped bacteria were observed, mostly in pairs or in small tri-dimensional microcolonies covering the root surface (Figure 5(C)). Bacteria were particularly accumulated in the basal portion of the root hair, forming micro aggregates on disrupted areas of the epidermal surface (Figures 5(D)-(E)). Such damage of the epidermal surface on heavily colonized areas suggested an active invasion mechanism, probably associated to a high density of bacterial population as compared to the non infected control plant (Figure 5(A)). The Bacteria were also found in disrupted zones of the mucigel (Figure 5(F)) in to the cells.
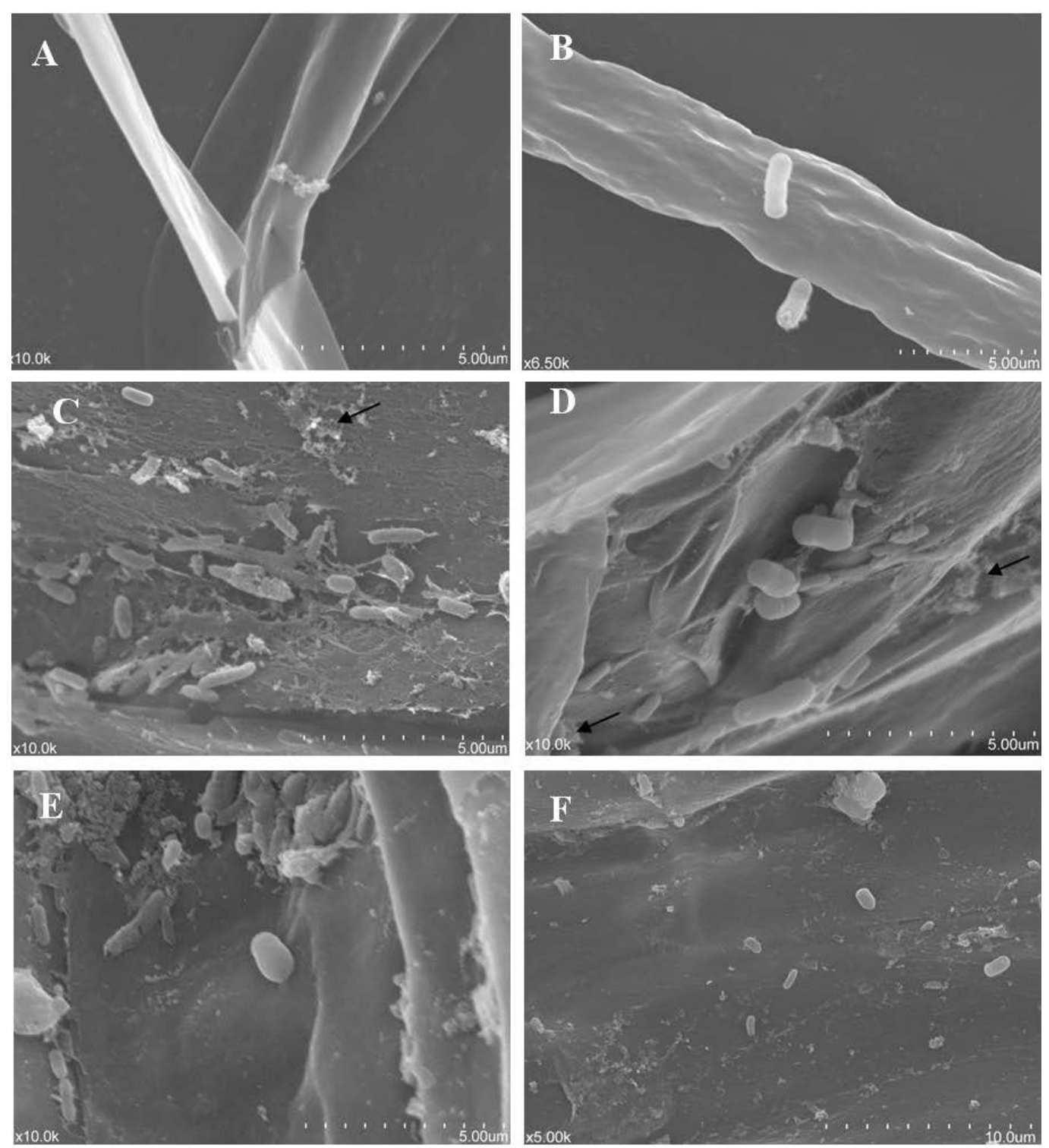

Figure 5. SEM study of root surface in rice seedlings of 14 days after inoculation of $P$. stutzeri. (A) Root surface of non-inoculated seedlings free of bacteria; (B) Attachment of the bacteria in root hair; (C) Root surface covered by endophytic bacteria, which showed adhesion filaments (arrow head) among them, and with the rhizoplane; (D) P. stutzeri micro colony consistently distributed on the surface of root; (E) High magnification of bacteria between the mucigel coat and the secondary roots; (F) Bacteria found in disrupted zones of the mucigel covering the grooves formed by the junctions among the epidermal cells. 


\subsection{Gene Expressions}

RT-PCR analyses of pilK, metE, rpoN and fdhE genes expression of P. stutzeri A1501 were performed A1501 with positive (with root exudates) and negative (control) conditions. After 1h, it was found that pilK, metE and $r p o N$ transcription were increased 5.7, 6.4 and 3.4-fold (Table 5), respectively, whereas in the fdhE gene has no expression. Consequently, after 4 h pilk, fdhE, metE and $r p o N$ were decreased $-1.9,-4.4,-0.2$ and -0.8 -fold, respectively. After $1 \mathrm{~h}$ it was noted that genes expression were up regulated, there were found no down regulated expression but after $4 \mathrm{~h}$ all genes expression were down regulated. These results indicated that up-regulated and down-regulated genes were important for bacterial root colonization. The relative expression levels of these genes were presented in Figure 6.

\section{Discussion}

\subsection{Organic Acids of Root Exudates}

The low molecular organic acids were tested in to the root exudates like acetic acid and tartaric acid; it was found that the concentrations were 19.84 and $324.12 \mu \mathrm{mol} \mathrm{g}^{-1}$ dry weight root, respectively (Table 4). These results had a similarity of low molecular weight organic acid concentrations of root exudates in acetic acid from Solanum nigrum L. was 36.56, and Solanum lycopersicum L. was 28.23; in tartaric Solanum nigrum L. was 280.12 and Solanum lycopersicum L. was 265.41 [21]. It was indicated that the quality of the root exudates remained unchanged in to the studied samples.

\subsection{Colonization of Rice Roots by P. stutzeri A1501}

The Gramineae rice (Oryza sativa L.) was chosen as a plant model in this study with the aim of investigating nitrogen-fixing $P$. stutzeri A1501 ability to colonize rice roots. A1501 is a versatile soil bacterium which has capacity of nitrogen fixation and endophytic association with rice plants. This association of A1501 with plants is a promising model system for the study of plant-microbe-soil interactions in the rhizosphere [22]. In the present

Table 5. Change of expression of genes during influence with root exudates.

\begin{tabular}{cccc}
\hline & & Change $(n$-fold $)$ & \\
\cline { 2 - 3 } Gene & 1 hour & 4 hours \\
\hline metE & 5.7 & -1.9 \\
rpoN & 6.4 & -0.2 \\
fdhE & 3.4 & -0.8 \\
\hline
\end{tabular}
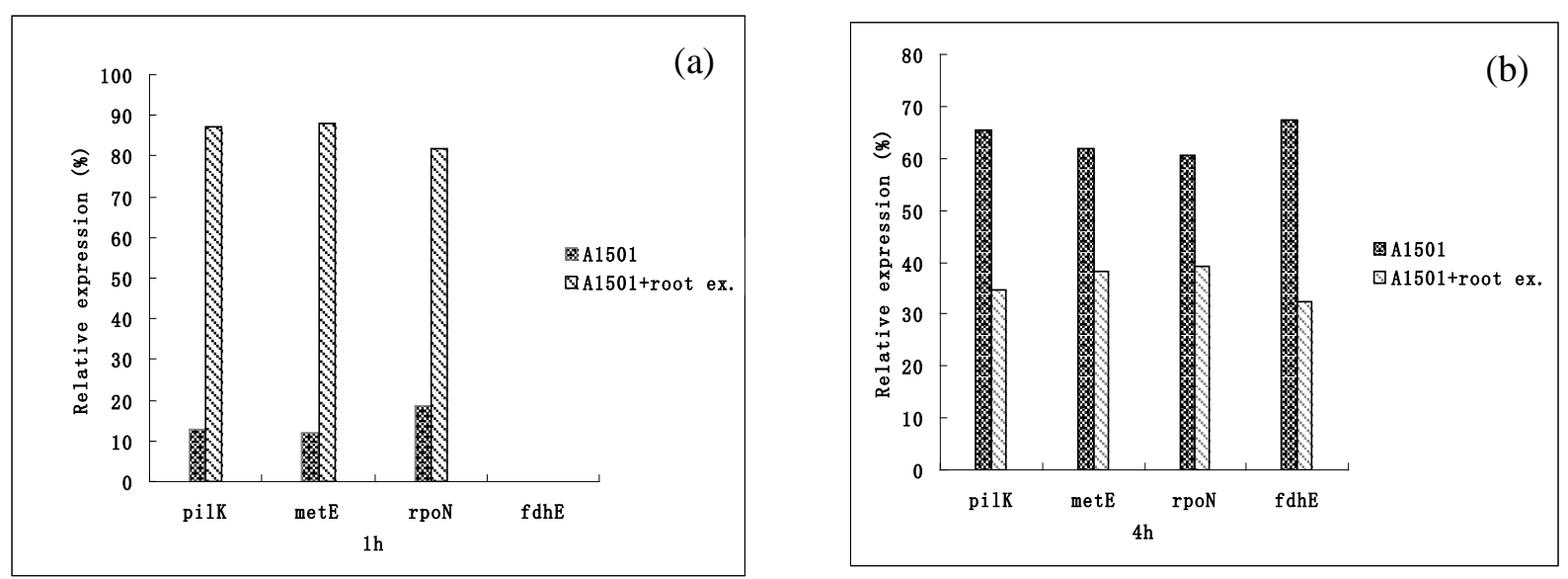

Figure 6. RT-PCR analysis of the $P$. stutzeri pilK, metE, rpoN and $f d h E$ genes expression after $1 \mathrm{~h}$ (a) and $4 \mathrm{~h}$ (b) induction of root exudates. 
study, it was demonstrated that $P$. stutzeri can invade rice roots, spreading rapidly and systematically through the root tissues and colonize rice roots. According to the results, endophytic P. stutzeri A1501bacteria were seem to be uniformly distributed on the rhizoplane of the root (Figure 5(C)); although, it identified the greatest density of bacteria at the intercellular junction (Figure 5(E)). This finding is probably due to the fact that intercellular regions represent more space and opportunity for the movement of endophytes; besides, very probably the mucilaginous layer, which covers the epidermis of the root, has a lower tension in these regions [23]. Previous reports indicated that, at the intercellular regions, there was an important increase in the concentration of carbon as a source of energy, thus explaining the preference of bacteria for this part of the root [24]. It has been suggested that microcolonies could develop on the surface of the epidermal cells and on the cellular junctions [23]. In addition, these results distinguished consecutive stages of $P$. stutzeri invasion in rice roots. The initial step consisted of the attachment of bacteria onto epidermal cells of the root surface, where root hair zone represent one of the major sites of primary colonization, mainly on the basal region of emerging hairs. At this stage, filamentous structures were observed in the microscopic analysis, apparently promoting bacteria-to-bacteria and bacteria-to-plant surface cross-linking (Figure 5(C) \& Figure 5(D)). Similar observations have been described in other endophytic interactions, resembling bacterial polysaccharide-like structures that may point to crucial stages of ligand-receptor apparatuses with significant potential to modulate the plant-bacteria interactions [25]-[27]. As observed in different plant-bacteria associations [28], surface polysaccharides such as exopolysaccharides and lipopolysaccharides (LPS) were involved in the colonization of roots. In a Tn5 mutant of A. brasilense affected in the biosynthesis ofd TDP-rhamnose, LPS composition was modified and resulted in impaired attachment of the mutant to maize roots and reduced root colonization [29]. Additional studies recently were undertaken on $H$. serepedicae by Balsanelli et al. [30] confirmed these data. In addition to LPS, a major outer membraneprotein from A. brasilense strain Cd was purified and shown, by in vitro adhesion assays, to bind to roots of wheat, corn and sorghum seedlings [31]. In addition to its involvement in root adsorption, this protein acted on cell aggregation of Azospirillum. Results indicated that the presence of many filaments cross-linking the endophytic bacteria and with the rhizoplane, suggesting a structural compatibility between endophytes and the vegetal cell wall. Evidence of a specific interaction of cyanobacteria with plant roots has been found with Nostoc 259B. This bacterium specifically interacts with wheat roots through a sequence of three neutral sugars and glucuronic acid; this interaction allows for an efficient colonization and exclusion of other colonizing cyanobacteria [32]. It were also identified high densities of endophytic bacteria in emerging zones from the lateral roots and, particularly, in the basal parts. This finding agrees with other studies indicating that these parts of the roots are highly susceptible to disruption, causing the release of endophytes [33]. Several investigators stated that the root colonization involves migration of bacteria towards the plantroots, adsorption and anchoring onto the root system, as well as microbial proliferation and the formation of microcolony/biofilm structures at the surface of roots [7] [34]-[37] that is consistent in our study.

\subsection{The Regulation of Gene Expression by Root Exudates}

In the present study, results indicated that $P$. stutzeri A1501, the expression of the number of genes were up regulated and down regulated in response to root exudates after $1 \mathrm{~h}$ and $4 \mathrm{~h}$ when compared with the control (Table 5 \& Figure 6). The genes of known function whose expression were up-regulated after $1 \mathrm{~h}$ in response to the root exudates were involved in aspects of metabolism such as aromatic compound catabolism, energy generation, and amino acid biosynthesis (Table 2). This finding is more expectable because organic acids, amino acids and monosaccharides is the major components of root exudates [38] that contribute to the influence of genes that may be important for plant-bacteria interactions. Lugtenberg et al. [38] showed that utilization of organic acid by Pseudomonas is the nutritional basis conducting the ability of colonization of this organism in tomato roots. The organic acids of root exudates are citric, acetic, tartaric, malic, lactic, and succinic acid which have the major exudates carbon sources helped to grow high bacterial population. In addition, the up-regulation of genes of bacteria involved likely to be colonization process [39].

Study on gene expressions, the gene pilK, up-regulated after $1 \mathrm{~h}$ and down-regulated after $4 \mathrm{~h}$ (Table 5), involved in twitching motility, encoding methyltransferase was a unique type of locomotion governing the ability of colonization of plant. This result consistent with $P$. aeruginosa, type 4 pili mediated the locomotion and involved in colonization of plant by associative nitrogen fixing of Azoarcus [40] [41]. Three genes metE, involved in amino acid biosynthesis and metabolism, encoding 5-methyltetrahydropteroyltriglutamate-homocysteine Smethyltransferase, $r p o N$ involved in amino acid biosynthesis, encoding RNA polymerase sigma-54 factor and 
fdhE involved in energy metabolism, encoding FdhE protein; these effects are unknown in root exudates for root colonization. These results consistent with Mark et al. [1] described that pilK and metE acted as twitching motility and; amino acid biosynthesis and metabolism for these reasons the effects of the genes are unknown. It was found that the diazotrophic employ an array of distinct mechanisms to colonize successfully the plant roots and compete with other soil microorganisms. Among the mechanisms, chemotaxis resulting from the presence of flagella allowed the bacteria to get into contact with roots, together with type IV pili and twitching motility. Twitching motility was based on a mechanism which includes pilus extrusion, surface attachment of the pilus tip, and pilus retraction to convey the bacterial cell to the point of attachment [42]. In Azoarcus, type IV pili were shown to be involved in adherence to plant surfaces and the pilA, pilB and pilT genes were essential for root-surface colonization and for infection of plant tissues in rice [8] [41] [42]. The expressions of the genes after $1 \mathrm{~h}$ and $4 \mathrm{~h}$, metE and $r p o N$ were up-regulated and down-regulated, respectively but $f d h E$ expression after $4 \mathrm{~h}$ was down-regulated and in $1 \mathrm{~h}$, there had no expression. It was noted that the identification of genes that are both up-and down-regulated irrespective of the level of expression in minimal lacted medium because it was plausible that down regulated of certain genes required for successful colonization. In Sugar beet, some genes expression in root exudates were down-regulated that were indicated as successful plant-microbe interaction [1].

\section{Conclusion}

It is concluded that $P$. stutzeri A1501 showed the ability of successful colonization of rice roots. The bacteria were uniformly distributed on the rhizoplane of the root and the density of bacteria was found at the intercellular junction. The genes, with known functions expression were up- and down-regulated, which indicated the plantmicrobe interaction in bacterial colonization in the rhizosphere. Being influenced in root exudates after $1 \mathrm{~h}$, it was found that pilK, metE and rpoN transcription were increased 5.7, 6.4 and 3.4-fold, respectively, whereas in the $f d h E$ gene had no expression. Consequently, after $4 \mathrm{~h}$ pilk, fdhE, metE and $r p o N$ were decreased -1.9, -4.4, -0.2 and -0.8 -fold, respectively. The gene pilK, expression was up-regulated after $1 \mathrm{~h}$ and down-regulated after $4 \mathrm{~h}$ that had twitching motility to convey the bacterial cell to point of attachment in to host plant.

\section{References}

[1] Mark, G.L., Dow, J.M., Kiely, P.D., Higgins, H., Haynes, J., Baysse, C., Abbas, A., Foley, T., Franks, A., Morrissey, J. and O'Gara, F. (2005) Transcriptome Profiling of Bacterial Responses to Root Exudates Identifies Genes Involved in Microbe-Plant Interactions. Proceedings of the National. Academy of Sciences of the United States of America, 102, 17454-17459. http://dx.doi.org/10.1073/pnas.0506407102

[2] Macario, B.J., Sara, A.F., Elsa, V.Z., Eduardo, P.C., Stephane, B. and Edgar, Z. (2003) Chemical Characterization of Root Exudates from Rice (Oryza sativa) and Their Effects on Chemotactic Response of Endophytic Bacteria. Plant and Soil, 249, 271-277. http://dx.doi.org/10.1023/A:1022888900465

[3] Hawes, M.C. and Pueppke, S.G. (1986) Isolated Peripheral Root Cap Cells: Yield from Different Plants, and Callus Formation from Single Cells. American Journal of Botany, 73, 1466-1473. http://dx.doi.org/10.2307/2443851

[4] Lynch, J.M. and Whipps, J.M. (1990) Substrate Flow in the Rhizosphere. Plant and Soil, 129, 1-10. http://dx.doi.org/10.1007/BF00011685

[5] Song, S.C. and Lin, L.P. (1999) The Transition of Rhizobium freedii Lipopolysaccarides Induced by Soybean Root Exudation. Botanical Bulletin of Academia Sinica, 40, 73-78.

[6] Morrissey, J.P., Dow, J.M., Mark, G.L. and O’Gara, F. (2004) Are Microbes at the Root of a Solution to World Food Production? Rational Exploitation of Interactions between Microbes and Plants Can Help to Transform Agriculture. EMBO Reports, 5, 922-926. http://dx.doi.org/10.1038/sj.embor.7400263

[7] Reinhold-Hurek, B. and Hurek, T. (2011) Living inside Plants: Bacterial Endophytes. Current Opinion in Plant Biology, 14, 435-443. http://dx.doi.org/10.1016/j.pbi.2011.04.004

[8] Krause, A., Ramakumar, A., Bartels, D., et al. (2006) Complete Genome of the Mutualistic, $\mathrm{N}_{2}$-Fixing Grass Endophyte Azoarcus sp. Strain BH72. Nature Biotechnology, 24, 1385-1391. http://dx.doi.org/10.1038/nbt1243

[9] Fouts, D.E., Tyler, H.L., DeBoy, R.T., Daugherty, S., Ren, Q., et al. (2008) Complete Genome Sequence of the $\mathrm{N}_{2}$-Fixing Broad Host Range Endophyte Klebsiella pneumoniae 342 and Virulence Predictions Verified in Mice. PLoS Genet, 4, e1000141.

[10] Yan, Y., Yang, J., Dou, Y., et al. (2008) Nitrogen Fixation Island and Rhizosphere Competence Traits in the Genome of Root-Associated Pseudomonas stutzeri A1501.Proceedings of the National Academy of Sciences of the USA, 21, 7564-7569. http://dx.doi.org/10.1073/pnas.0801093105 
[11] Bertalan, M., Albano, R., de Pa'dua, V., et al. (2009) Complete Genome Sequence of the Sugarcane Nitrogen-Fixing Endophyte Gluconacetobacter diazotrophicus PAl5. BMC Genomics, 10, 450. http://dx.doi.org/10.1186/1471-2164-10-450

[12] Kaneko, T., Minamisawa, K., Isawa, T., et al. (2010) Complete Genomic Structure of the Cultivated Rice Endophyte Azospirillum sp. B510. DNA Research, 17, 37-50. http://dx.doi.org/10.1093/dnares/dsp026

[13] Pedrosa, F.O., Monteiro, R.A., Wassem, R., et al. (2011) Genome of Herbaspirillum seropedicae Strain SmR1, a Specialized Diazotrophic Endophyte of Tropical Grasses. PLoS Genetics, 7, e1002064. http://dx.doi.org/10.1371/journal.pgen.1002064

[14] Cartieaux, F., Thibaud, M.C., Zimmerli, L., et al. (2003) Transcriptome Analysis of Arabidopsis Colonized by a PlantGrowth Promoting Rhizobacterium Reveals a General Effect on Disease Resistance. The Plant Journal, 36, 177-188. http://dx.doi.org/10.1046/j.1365-313X.2003.01867.x

[15] Verhagen, B.W.M., Glazebrook, J., Zhu, T., Chang, H.S., van Loon, L.C. and Pieterse, C.M.J. (2004) The Transcriptome of Rhizobacteria-Induced Systemic Resistance in Arabidopsis. Molecular Plant-Microbe Interactions, 17, 895908. http://dx.doi.org/10.1094/MPMI.2004.17.8.895

[16] Cheng, Z., McConkey, B.J. and Glick, B.R. (2010) Proteomic Studies of Plant Bacterial Interactions. Soil Biology and Biochemistry, 42, 1673-1684. http://dx.doi.org/10.1016/j.soilbio.2010.05.033

[17] Walker, V., Bertrand, C., Bellvert, F., Moënne-Loccoz, Y. and Bally, R. (2011) Host Plant Secondary Metabolite Profiling Shows a Complex, Strain-Dependent Response of Maize to Plant Growth-Promoting Rhizobacteria of the Genus Azospirillum. New Phytologist, 189, 494-506. http://dx.doi.org/10.1111/j.1469-8137.2010.03484.x

[18] Hoagland, D.R. (1975) Mineral Nutrition. In: De Kaufman, P.B., Labavitch, J., Anderson-Prouty, A. and Ghosheh, N.S., Eds., Laboratory Experiments and Plant Physiology, Macmillan Publishing Co. Inc., New York, 129-134.

[19] Rediers, H., Bonnecarrère, V., Rainey, P.B., Hamonts, K., Vanderleyden, J. and De Mot, R. (2003) Development and Application of a dapB-Based in Vivo Expression Technology System to Study Colonization of Rice by the Endophytic Nitrogen-Fixing Bacterium Pseudomonas stutzeri A15. Applied and Environmental Microbiology, 69, 6864-6874. http://dx.doi.org/10.1128/AEM.69.11.6864-6874.2003

[20] Keitaro, T., Ryota, H., Takuro, S., Tadao, W., Kazuki, S. and Akira, O. (2009) Metabolite Profiling of Rice Root Exudate under Phosphorus Defficiency. Proceedings of the International Plant Nutrition Colloquium XVI, Sacramento, 26-30 August 2009.

[21] Bao, T., Sun, T. and Sun, L. (2011) Low Molecular Weight Organic Acids in Root Exudates and Cadmium Accumulation in Cadmium Hyper Accumulator Solanum nigrum L. and Non-Hyper Accumulator Solanum lycopersicum L. African Journal of Biotechnology, 10, 17180-17185.

[22] Yan, Y., Ping, S., Peng, J., Han, Y., Li, L., Yang, J., et al. (2010) Global Transcriptional Analysis of Nitrogen Fixation and Ammonium Repression in Root-Associated Pseudomonas stutzeri A1501. BMC Genomics, 11, 11. http://dx.doi.org/10.1186/1471-2164-11-11

[23] Bowen, G.D. (1979) Integrated and Experimental Approaches to the Study of Growth of Organisms around Roots. In: Schippers, B. and Gams, W., Eds., Soil-Borne Plant Pathogens, Academic Press, London, 207-227.

[24] Bennet, R.A. and Lynch, J.M. (1981) Bacterial Growth and Development in the Rhizosphere of Gnotobiotic Cereal Plants. Journal of General Microbiology, 125, 95-102. http://dx.doi.org/10.1099/00221287-125-1-95

[25] Bacilio-Jiménez, M., Aguilar-Flores, S., Del Valle, M.V., Pérez, A., Zepeda, A. and Zenteno, E. (2001) Endophytic Bacteria in Rice Seeds Inhibit Early Colonization of Roots by Azospirillum brasilense. Soil Biology and Biochemistry, 33, 167-172. http://dx.doi.org/10.1016/S0038-0717(00)00126-7

[26] Ramey, B.E., Koutsoudis, M., Von Bodman, S.B. and Fuqua, C. (2004) Biofilm Formation in Plant Microbe Associations. Current Opinion in Microbiology, 7, 602-609. http://dx.doi.org/10.1016/j.mib.2004.10.014

[27] Roncato-Maccari, L.D., Ramos, H.J., Pedrosa, F.O., Alquini, Y., Chubatsu, L.S., Yates, M.G., Rigo, L.U., Steffens, M.B. and Souza, E.M. (2003) Endophytic Herbaspirillum seropedicae Expresses nif Genes in Graminous Plants. FEMS Microbiology Ecology, 45, 39-47.

[28] Gough, C. and Cullimore, J. (2011) Lipo-Chitooligosaccharide Signaling in Endosymbiotic Plant-Microbe Interactions. Molecular Plant-Microbe Interactions, 24, 867-878. http://dx.doi.org/10.1094/MPMI-01-11-0019

[29] Jofre, E., Lagares, A. and Mori, G. (2004) Disruption of dTDP-Rhamnose Biosynthesis Modifies Lipopolysaccharide Core, Exopolysaccharide Production and Root Colonization in Azospirillum brasilense. FEMS Microbiology Letters, 231, 267-275. http://dx.doi.org/10.1016/S0378-1097(04)00003-5

[30] Balsanelli, E., Serrato, R.V., de Baura, V.A., Sassaki, G., Yates, M.G., Rigo, L.U., et al. (2010) Herbaspirillum seropedicae $r f b B$ and $r f b C$ Genes Are Required for Maize Colonization. Environmental Microbiology, 12, 2233-2244.

[31] Burdman, S., Dulguerova, G., Okon, Y. and Jurkevitch, E. (2001) Purification of the Major Outer Membrane Protein of Azospirillum brasilense, Its Affinity to Plant Roots, and Its Involvement in Cell Aggregation. Molecular Plant-Microbe Interactions, 14, 555-561. http://dx.doi.org/10.1094/MPMI.2001.14.4.555 
[32] Gantar, M.P., Rowell, N.W., Kerby, N. and Sutherland, W. (1995) Role of Extracellular Polysaccharide in the Colonization of Wheat Triticum vulgare L. Roots by $\mathrm{N}_{2}$-Fixing Cyanobacteria. Biology and Fertility of Soils, 19, 41-48. http://dx.doi.org/10.1007/BF00336345

[33] Agarwhal, S. and Shende, T.S. (1987) Tetrazolium Reducing Microorganisms Inside the Root of Brassica Species. Current Science, 56, 187-188.

[34] Reinhold, B., Hurek, T., Niemann, E.G. and Fendrik, I. (1986) Close Association of Azospirillum and Diazotrophic Rods with Different Root Zones of Kallar Grass. Applied and Environmental Microbiology, 52, 520-526.

[35] Alexandre, G. and Zhulin, I.B. (2007) Chemotaxis in Soil Diazotrophs: Survival and Adaptative Response. In: Elmerich, C. and Newton, W.E., Eds., Associative and Endophytic Nitrogen-Fixing Bacteria and Cyanobacterial Associations, Kluwer Academic Publishers, Dordrecht, 73-84. http://dx.doi.org/10.1007/1-4020-3546-2_4

[36] Vanbleu, E. and Vanderleyden, J. (2007) Molecular Genetics of Rhizosphere and Plant-Root Colonization. In: Elmerich, C. and Newton, W.E., Eds., Associative and Endophytic Nitrogen-Fixing Bacteria and Cyanobacterial Associations, Kluwer Academic Publishers, Dordrecht, 85-112. http://dx.doi.org/10.1007/1-4020-3546-2 5

[37] Compant, S., Clément, C. and Sessitsch, A. (2010) Plant Growth-Promoting Bacteria in the Rhizo- and Endosphere of Plants: Their Role, Colonization, Mechanisms Involved and Prospects for Utilization. Soil Biology and Biochemistry, 42, 669-678. http://dx.doi.org/10.1016/j.soilbio.2009.11.024

[38] Lugtenberg, B.J., Dekkers, L. and Bloemberg, G.V. (2001) Molecular Determinants of Rhizosphere Colonization by Pseudomonas. Annual Review of Phytopathology, 39, 461-490. http://dx.doi.org/10.1146/annurev.phyto.39.1.461

[39] Sarkar, A. and Reinhold, H.B. (2014) Transcriptional Profiling of Nitrogen Fixation and the Role of NifA in the Diazotrophic Endophyte Azoarcus sp. Strain BH72. PLoS ONE, 9, e86527. http://dx.doi.org/10.1371/journal.pone.0086527

[40] Darzins, A. and Russell, M.A. (1997) Molecular Genetic Analysis of Type-4 Pilus Biogenesis and Twitching Motility Using Pseudomonas aeruginosa as a Model System—A Review. Gene, 192, 109-115. http://dx.doi.org/10.1016/S0378-1119(97)00037-1

[41] Dorr, J., Hurek, T. and Reinhold, H.B. (1998) Type IV Pili Are Involved in Plant-Microbe and Fungus-Microbe Interactions. Molecular Microbiology, 30, 7-17. http://dx.doi.org/10.1046/j.1365-2958.1998.01010.x

[42] Bohm, M., Hurek, T. and Reinhold-Hurek, B. (2007) Twitching Motility Is Essential for Endophytic Rice Colonization by the $\mathrm{N}_{2}$-Fixing Endophyte Azoarcus sp. Strain BH72. Molecular Plant-Microbe Interactions, 20, 526-533. http://dx.doi.org/10.1094/MPMI-20-5-0526 